\title{
Folklore from the Southern Sporade
}

\section{W. H. D. Rouse M.A.}

To cite this article: W. H. D. Rouse M.A. (1899) Folklore from the Southern Sporade, Folklore, 10:2, 150-185, DOI: 10.1080/0015587X.1899.9720491

To link to this article: http://dx.doi.org/10.1080/0015587X.1899.9720491

$$
\text { 曲 Published online: } 14 \text { Feb } 2012 .
$$

5 Submit your article to this journal $₫$

Q View related articles $ᄃ$ 


\section{FOLKLORE FROM THE SOUTHERN SPORADES. ${ }^{+}$}

By W. II. D. Rouse, M.A.

\section{(Read at Meeting of 2oth December, 1898. )}

IN a previous paper ${ }^{2}$ I set before the Folk-Lore Society some notes of the manners and customs of the people of Lesbos. I have now another small budget of notes, chiefly from the island of Cos. The group of islands between Cos and Patmos is almost untouched ground. There exists no book about Cos, so far as I have been able to discover. Patmos is described in a Russian work which I have tried in vain to procure. Small pamphlets have appeared on one or two other of the islands thereabouts, but I am convinced that the harvest is still to be reaped. Patmos and Calymnos I must leave for another occasion, and I have plenty of material from the former at least to fill a paper.

I have not tried to complete the record by use of printed books, although I shall refer to one or two by the way." This would have increased my paper to a great bulk; and besides, the books are not inaccessible. It seemed to me that it would be more useful to give what I had got at first hand; and even if some of these things are already printed, a new and independent record has its value. However, very few of them are printed: such will be noted in their place. Most of the notes on Cos I owe to the kindness of

"I have to thank Mr. W. R. Paton and "Argyris Eftallots" for kindly looking through the proofs of this paper. They have enabled me to clear up many obscure points.

Vol, vii, p. 142.

- E.g. Schmidt, Leben der Neugriechen: Thumb, Der Ktidonas, Die Schicksalsgöttinen (Ztsch. des Vereins f. Volkskunde, 1892, p. 392, 123); Kanellakis,

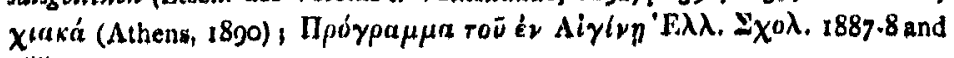
¿889.90. 
Mr. Jacobus Zarraftes, who knows the dialects, poems, stories, and customs of the island as probably no other man does.

In addition to this, I have made use of four manuscripts which lately came into my possession in the same neighhourhood. Three of them are bodies of ecclesiastical canon law.' The fourth is a very curious manuscript of charms and incantations, piety and astrology, compiled just a hundred years since by a certain Georgios, who was the great-grandfather of Mr. Zarraftes, whom I have already mentioned.

I shall first give the extracts from these MSS., which touch upon our subject. Next will come a chapter on hobgoblins, with a batch of notes on times and seasons and other small matters; and finally a poem which embodies the legend of human sacrifice.

\section{J.-Magic and Divination.}

As the Fathers of the Church, and the holy synods, fortunately for us, denounced the works of the devil in some detail, they have preserved a good deal of information for our benefit. I hope some day to be able to go though the whole of the Nopoxavóves; for the present I shall confine myself to my own three MSS. In one of them ${ }^{2}$ those persons are accused who believe in such things as a witch, or a Moré, or a Gyloú, and love them. The Gyloúdes are explained to be "women who suck the blood of babes and kill them." The name and the belief go back as far at

' (i.) One appears to be in a fifteenth-century hand; (il.) another is dated, from internal evidence, 1560 ; (iii) the third is probably a little later.

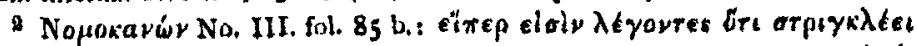

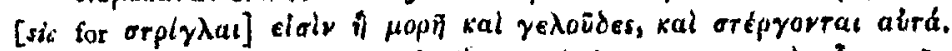

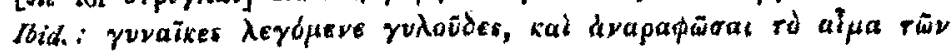
Bpeqiù val Oavaroũoty aird. In quoting from these MSS. I keep the spelling, but write the accents and uspirates according to rule. 


\section{Folklore from the Southern Sporades.}

least as Zenobius, who collected proverbs in the second century, A.D. ${ }^{1}$; and, if he is to be believed, even to Sappho. Hesychius, a lexicographer of Constantinople, also mentions Gello. The following passages contain a small corpus of black and white magic. Penance is imposed on the "wizard or soothsayer, and the wax-melter, and the lead-melter, or whoso bespells the beasts, or 'binds' the wolf from eating them, or binds a married couple from having children, or who works charms against sickness. . . . . Now wizards are those who draw the demons to them by enchantment, binding them according to their own will, and who bind creeping things that they hurt not the beasts if they happen to be abroad."

Astrologers ${ }^{8}$ are also mentioned, and Egyptian women, ${ }^{4}$ or Gypsies, as working spells and divining of the future. "Those who practise divination by barley," we read," "or by beans, and all such as wear amulets made of plants or any such thing, and put colours upon their children or beasts against the Evil Eye. . . . He that calls in magicians

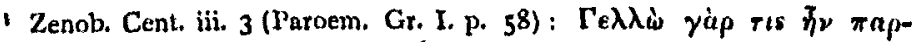

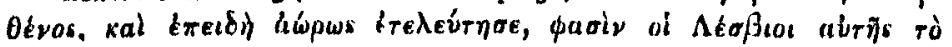

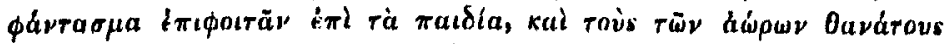

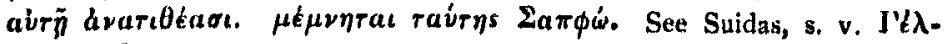
$\lambda \omega s \pi a t \delta o \phi i \lambda \omega r e ́ p a$, doubtless Sappho's words. Sce also Schmidl, Das Volksleben der Neugriechen, p. I39.

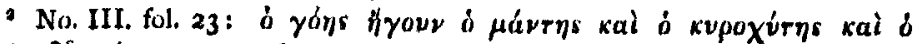

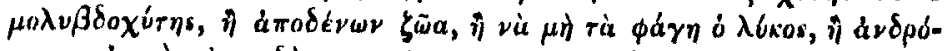

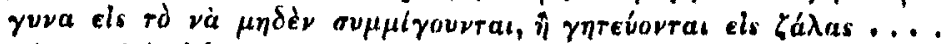

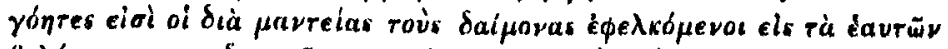

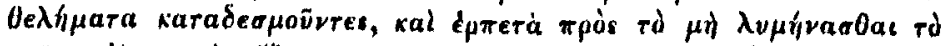

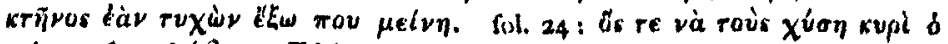

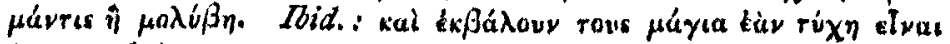

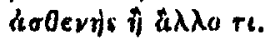

8 i) darpovouoũrtat, fol. 24 .

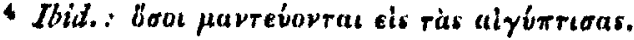

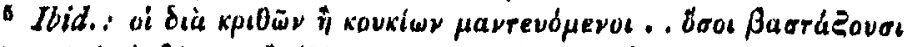

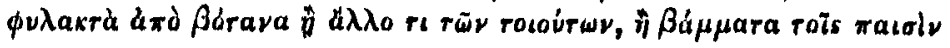


to do magic for the hurt of others. . . . They who carry about bears or other beasts as playmates for the hurt of simpler folk, or who drive away (?) the clouds, or who provide amulets, or believe in Luck and Fate and horoscopes, that it is good to be born on one day and bad on another, or omens of chance words, or who put on colours, that is to

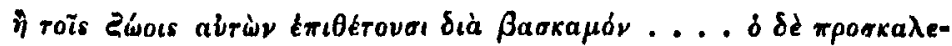

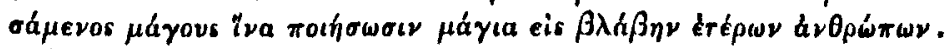

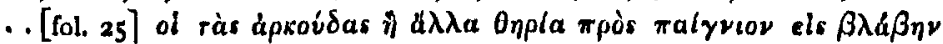

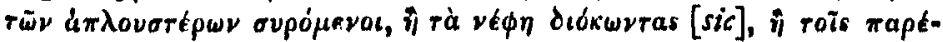

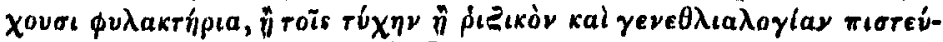

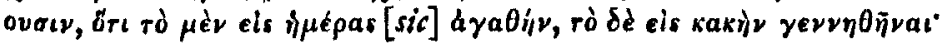

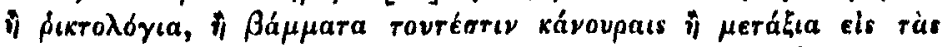

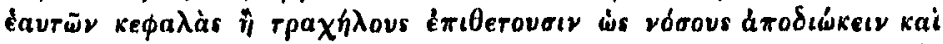

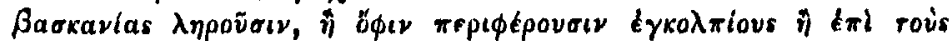

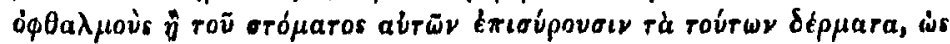

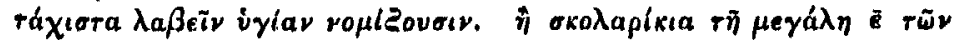

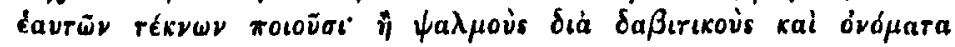

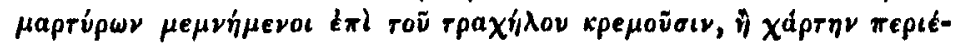

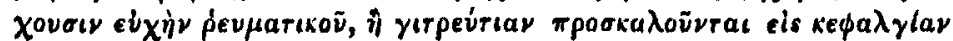

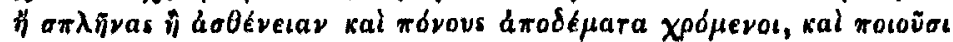
"Xolvia e $\pi$ tKa

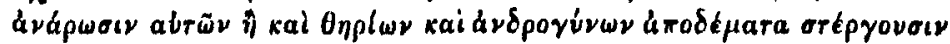

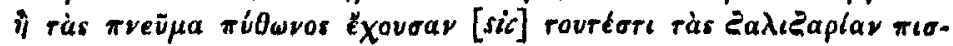

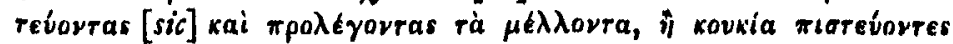

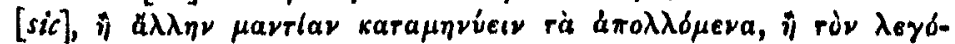

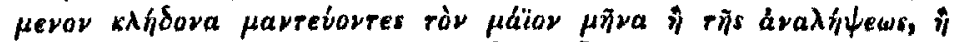

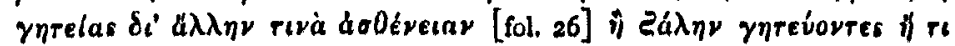

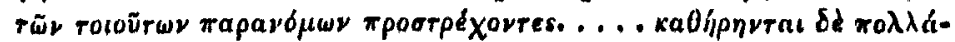

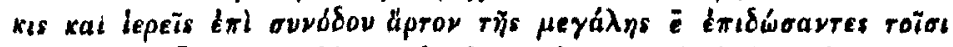

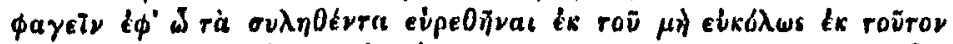

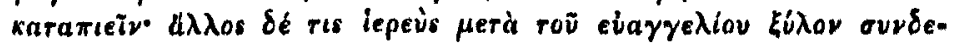

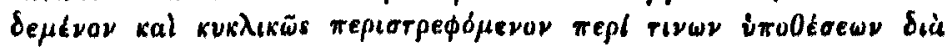

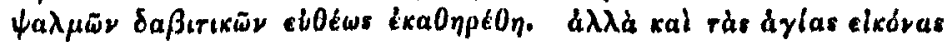

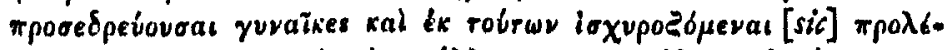

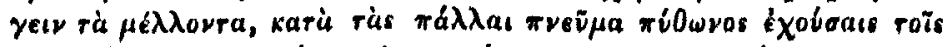

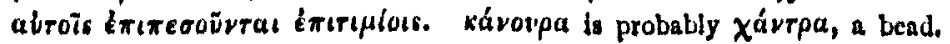
It is thus accented in the MS. 


\section{Folklore from the Southern Sporades.}

say, beads or silk upon their heads or necks to keep off diseases, and talk folly about the Evil Eye, or who carry about a snake in their bosom, or pass the skins of snakes over their eyes or mouth, which they think will bring health quickly ; or who make earrings for their children on Holy Thursday, or con the Psalms of David or names of the Martyrs, and hang them about their necks; or fasten on them a paper with a prayer against rheumatism, or call in a wise woman to prevent head-ache, or spleen, or illness and pains, using 'binding'-spells; or who plait cords, calling upon the good demons for help and healing; or who love spells that 'bind' beasts and married folk, or women that have the spirit of Pytho, that is to say, those who believe in second sight (?) and foretell the future, or who believe in beans or anything else to discover that which is lost, or who divine by what is called the Voice (Kledonas) in the month of May, or at the Ascension, or use charms for any other illness, or bespell sickness, or run after any such unlawful thing. . . Many times priests have been degraded in a synod after giving the Holy Bread on Holy Thursday to persons to eat, for the purpose of finding out things stolen, because (the thieves) could not easily swallow this down; another priest, again, was degraded for causing a bundle of sticks to be carried round in a circle while the gospel was being read, for certain reasons, to the sound of David's psalms; and even the holy icons are beset by women, who say that from these icons they can foretell the future."

Most of these allusions explain themselves; we have heard before of amulets, soothsaying, the food-ordeal, snake-charms, and gospel charms. The "divination by barley" may be a food-ordeal, or a counting formula like the well-known "Loves me, loves me not." The virtue of "colours" is still believed in; and blue beads are hung about a child's neck, or worked into the trappings of a mule. The name "Pytho" is a curious survival, which we find even 
in the west; Reginald Scot has a chapter" "How the lewd practise of the Pythonist of Westwell came to light, and by whome she was examined," and many other allusions to these wise women. Bears are still regarded in the east as possessed of magical properties." When they are brought round to an Indian village, sick children are made to ride on them for a cure; and magical potions and drugs are made with their claws or hair. ${ }^{8}$ Mr. Paton in 1894 found bears' hairs and claws held potent against the Evil Eye and fevers in Lesbos. ${ }^{4}$ The sticks were probably wrapped in paper, with texts from the Psalms written on them, in order to find out something.

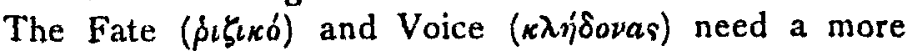
detailed examination. $\dot{\rho} \iota \zeta_{\iota} \kappa o^{\prime}$ appears to be the Italian risico, rischio, "risk," "chance;" and it is used in Greek for

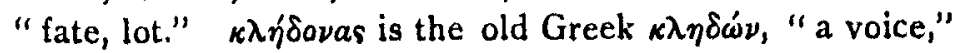
hence "an omen." The custom for AEgina has been

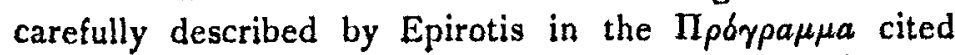
above; and it has also been noted in Thessaly and Cyprus, to which I now add Cos. It is a mode of divination for the married and the unmarried alike. In Egina the custom is as follow's: On the eve of St. John's Day, a girl collects from all those who wish to take part some token, a ring or what not, and puts them in a jar never used before. This is then filled with water ( $\rho_{\imath} \zeta_{\iota}$ inóve $\left.\rho 0\right)$, which must be drawn

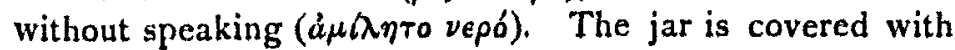
a red cloth and adorned with myrtle and laurel, at which certain verses are spoken. The jar is left out all night, and brought in at sunrise. Then a boy, with a red cloth over his head, uncovers the jar, while one of the girls

1 Discovery of Wilchiraft, p. 130, ed. 1584.

" My authority is Mr. W. Crooke.

- North Indian Notes and Queries, vol. Iv. 8465.

- See a note by him in Folk-Loro, vol. vi. p. 90, and also vol, v. p. 275. The MSS, referred to in the last note are those I now have, Nos. I.-III. Sec also Grimm, Afyth., p. 743 ; Weistumer, vol. I. p. 533. 


\section{I56 Folklore from the Southern Sporades.}

repeats another couplet. Then a girl repeats one of the couplets traditional for this occasion, and the boy takes out one of the tokens, to whose owner it is supposed to apply. The married women make preparations in like manner, but with them it is but a jest. The verses repeated for them are such as this: "Get on a pig and ride about," or "Take bread and biscuit and keep an eye on the ass."

But there is another kind of charm which is very common in Greece, the so-called $\delta \varepsilon^{\prime} \mu a(\dot{a} \pi \dot{\delta} \delta e \mu a)$ or "binding-spell." Married couples are especially afraid of being thus bewitched during the wedding ceremony, and commonly some counter-charm is done by way of protection. Something was said of this in my paper on Lesbos, but this time I have found quite a treasure in my fourth MS. This curious document was written (or finished) in 1799 by one Georgios, of Calymnos, the "servant of God," as he delights to call himself. The MS. has been in perils by fire and perils by water; it has lost its beginning and its ending; the spelling is atrocious; it is execrably written by several hands or in several kinds of handwriting, and apparently at different dates, as the servant of God collected his material. In it there are love-charms, medical charms, and astrological notes, and there are several which undo the "bindingspells" we are now speaking of. The following are the chief of them.

The first charm in the book begins in the middle, a leaf or leaves having been lost. After many prayers, which have small interest, for deliverance from "every binding, counter-binding, all magic and mischief," intermingled with cabalistic signs, such as two triangles interlocked

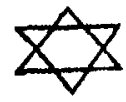

\footnotetext{
In quoting the Greek I have modernised the spelling, otherwise the extracts would hardly be intelligible to the classical atudent. A few certain restorations of the ends of words have been made.
} 


\section{Folklore from the Southern Sporades.}

or rows of meaningless letters, the following directions are given (fol. 1) : ${ }^{1}$

(I) "For loosing of a married couple; to be done when you will, that you may loose them. A spiritual person or priest, on a large white platter ${ }^{2}-$ write first thus ${ }^{3}$

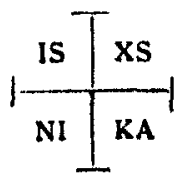

Then write the $35^{\text {th }}$ Psalm, which says, 'The unrighteous

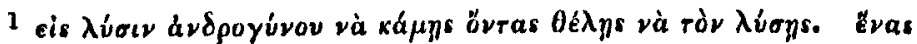

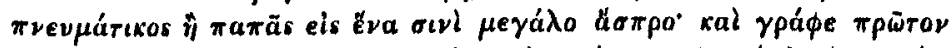

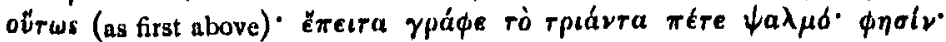

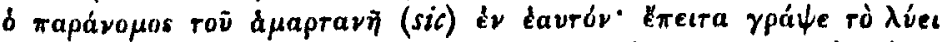

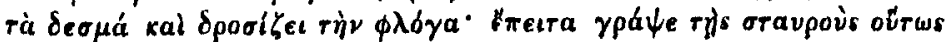

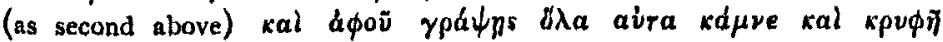

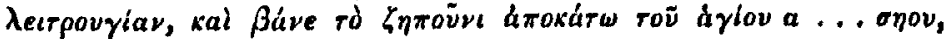

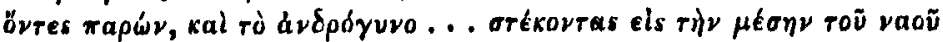

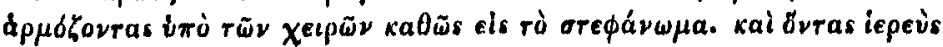

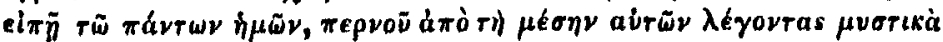

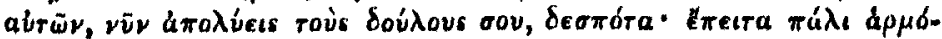

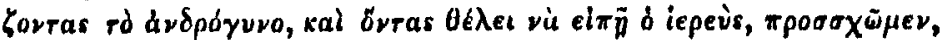

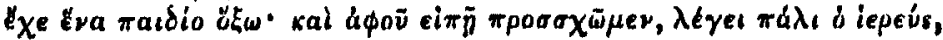

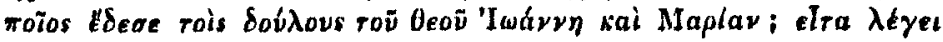

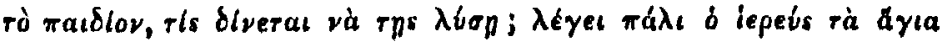

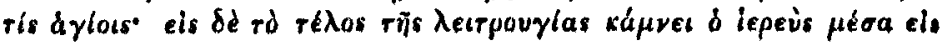

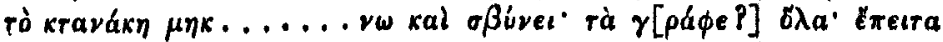

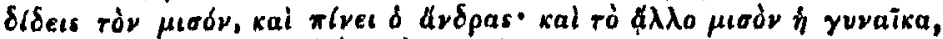

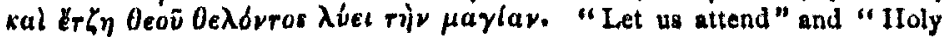
things to the holy " are cues in the Greek Liturgy. Seo J. N. W. B. Robertson's Liturgios, Nutt, p, 392. The word a .... nou has $\eta$ clearly written but it may be mistake for á $y \iota a \sigma \mu o \tilde{u}$.

- The meaning is not that the priest is on the platter, but the construction breaks off. It should continue "let him write." Much of the language is very obscure.

' i.e, 'Inooũs X Xı vol. vill p. 349. The same symbol is on the wooden stamps used for stamping Church Bread. A specimen is sent for the Society's Museum.

- This is misquoted from the 3 Gth Psalin according to our Bible. 


\section{${ }^{158}$ Folklore from the Southern Sporades.}

hath an oracle of sin within him.' Then write: 'Looseth the bonds and quencheth the flame.' " Then write the crosses after this fashion-2

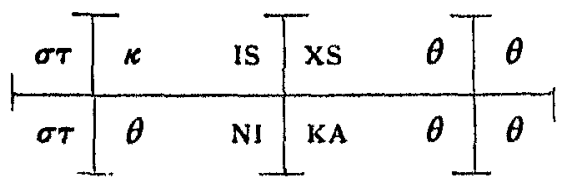

and after you have written all this, secretly perform the service and place the sacred [elements?] beneath the priest's coat, ${ }^{,}$the married pair being also present; standing in the midst of the church, joining them under his hands as at the crowning (i.e. wedding); and when the priest says the words 'Of us all', pass between the pair, saying secretly, 'Now, $O$ Lord, thou dost set free thy servants.' Then again joining the pair; and when the priest will say 'Let us attend,' have a child ready outside ; and after the priest has said 'Let us attend,' the priest says again: 'Who has bound the servants of God, Joannes and Maria?' Then the boy says: 'Who can set them free?' Again the priest says: 'Holy things to the holy,' and at the end of the service, the priest does the service within the cupboard 4 and quenches the [illegible].

"Write (?) all this; then you give the half, and the man drinks it, and the woman the other half, and God willing this looses the spell."

The state of the MS. is so damaged that much is left doubtful, yet there is enough to show that the charm was worked during the marriage service, or in a repetition of it ;

- Part of a hymn sung on Ascension Day.

$2 \operatorname{ar}(a u p d s) k(u p l o v), \operatorname{ar}(a u p d a) \theta(e o \tilde{)})$, the rest as above.

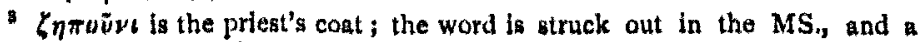
later hand writes oivl, "platter,"

4 In the iepos, where the sacred elements are kept. 
there is a child, who perhaps is necessary on the principle of sympathetic magic; and some drink is shared between man and wife. ${ }^{2}$ The passing of some person between the pair is perhaps meant to break the invisible binding spell. Reginald Scot says: "It is thought verie ill lucke of some, that a child, or any other living creature, should passe betweene two friends as they walk togither; for they say it portendeth a division of friendship." "

(2) The second charm" ${ }^{3}$ runs: "To set free a married pair in another fashion, easily and without trouble. Find three wild olive trees, which have been grafted several days, when their grafting has not taken, let them be all three on a row. Take their bindings and the earth of them, without speaking, on Saturday in the evening. Take them and put them in a boiler, and put water in it; boil them together, and let the man and wife wash together with that water, without speaking, and let them come together without speaking; and let that water also be brought from the spring without speaking." Here the sympathetic magic is clearer still.

(3) "At midnight let a man who is not 'bound' come together with his wife, without speaking; then wearing the same garments he had on, let him arise and go to the house of him who is 'bound.' Let him knock without speaking.

1 Probably holy water washed over the charm, See below, p, I7I.

- Discovery, p. 204.

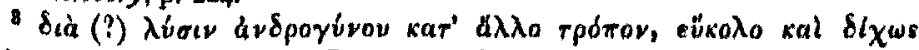

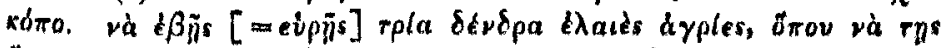

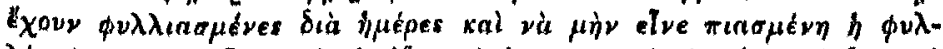

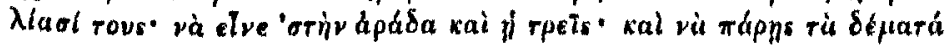

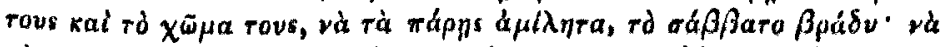

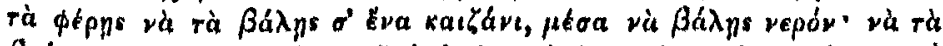

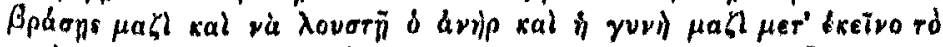

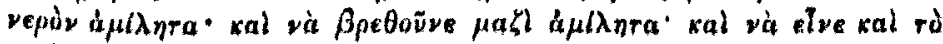

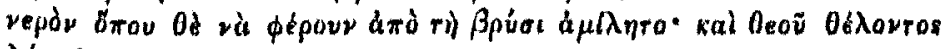

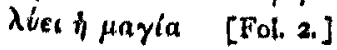




\section{Folklore from the Southern Sporades.}

Let him who is bound arise without speaking (neither he nor his wife), to open the door. Let the man who has been with his wife take off his clothes, and taking them all off, let them put on each the clothes of the other; let the bespelled man put on the other man's clothes inside out, and without shutting the door let him go to his wife, not speaking; and without the wife of the first man speaking, the man who would come to knock at the other man's door; and let him go and knock at the door, and without looking behind him: when the bespelled man has put on the other man's clothes, and when he has been with his wife, let him say, 'Now set free, O Lord, thy servants Eustathios and Maria.'" 1

(4) "To loose a married pair easily: Find in the month of May two snakes which are casting skins. Kill them and take their heads, and let the man have them on him when he goes to his wife. The spell will be loosed, even if it have been shot out of a gun or cast into the sea." a Curses

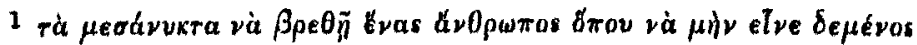

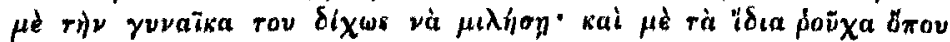

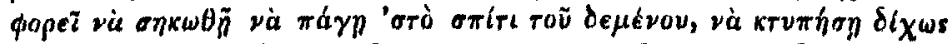

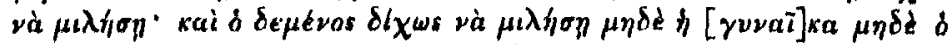

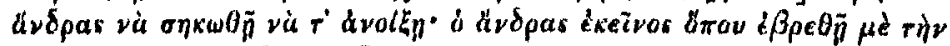

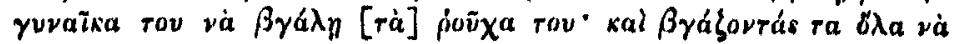

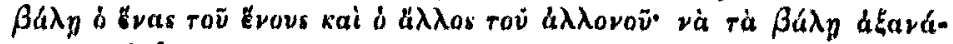

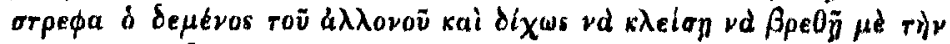

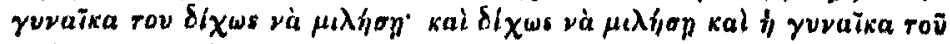

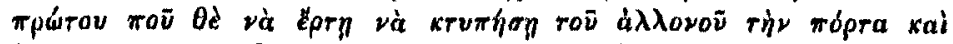

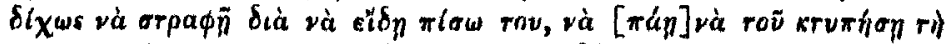

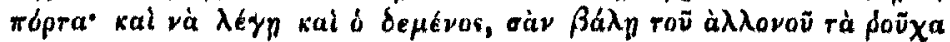

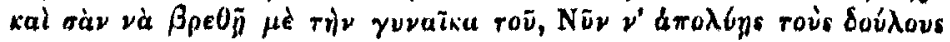
oov dearó́ta Eivaríatov kai Maplay. [Fol. 2, 3.]

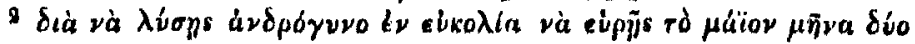

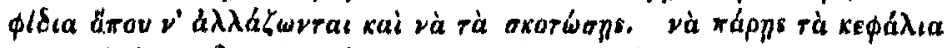

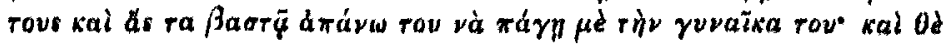
$\lambda$ fop [Fol. ar.] 


\section{Folklore from the Southern Sporades. I61}

were cast into the sea in ancient times; but I do not recollect hearing before of this other mode of making the spell effective by shooting it from a gun.

(5) "Qui morbo eo laborat, advehat ad genitalia sua vulvam ursae, coeatque cum uxore. ... Idem facit et lupa vulva, qua idem fac." 1

The Binding of Beasts is another kind of charm mentioned in the extracts from the canons given above. This was of two kinds : wild beasts might have a spell cast over them to prevent mischief, and tame beasts might be injured and made barren or useless. Of the first sort I have no specimen whatever in my MS., but there died lately in Cos an old man of the village of Aspendiou who knew such

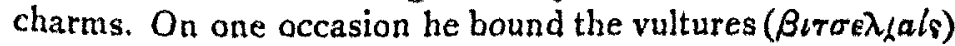
after this fashion: A girl had to be found who must be sixteen years of age. Found, the old man gave her some silk, which she twisted into a thread exactly as long as she was tall. This she gave to the man, who secretly rose up before day ( went to a wild olive tree, which must be invisible from the sea; upon this he tied the thread in three knots, reciting a charm. His fee was five pounds, a large sum for a poor famine-stricken hamlet.

In my magical MS., however, there are many prayers for a blessing upon the sheep and cattle, interspersed with mystic signs, crosses, and letters. There are allusions to those who "bind" the clouds that they rain not, and the trees and vines that they bear no fruit, the flocks and herds that they breed no young and give no milk, prayers against the machinations of demons and evil men, of Assyrians, Chaldaans, Persians, Arabs, Saracens, Egyptians, Libyans,

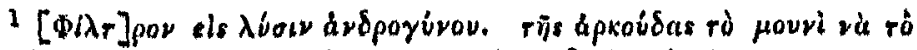

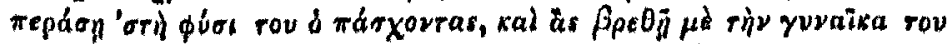

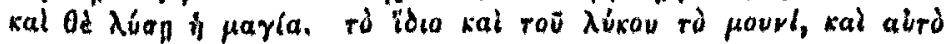
sápe tó. [Fol, 21.]

vOL. $\mathbf{x}$. 


\section{Folklore from the Southern Sporades.}

Sarnaritans, Phœnicians, Pisidians, Paphlagonians, Galatre, Phrygians, Bulgarians, Dardanians, Germans, Spaniards, Romans, Gauls, Turks, Tartars, Unicorns, Cynoscephalians, women with one breast, Allemanni, Wallachians, and many mote whose names I never heard of. The great spirits Serachia, Eligdeos, Adonai, Sabaoth, and all those whom King Solomon bound by oath, are invoked. A demon, interviewed by the Archangel Michael, gives at command a list of his names; these are, $\sigma \tau \rho i \gamma \lambda a, \gamma i \lambda_{0} \hat{v}, \mu o \rho \phi o \hat{v}$,

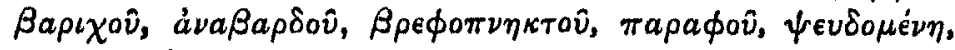

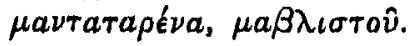

There are still, current many of these beast-binding charms. From Lesbos I got one or two which have.been already given to this Society, and I now add another from an old dame at Cos, aged ninety or more. Sometimes a mother wants to go out to work, leaving her children at home; then she repeats the following lines:-

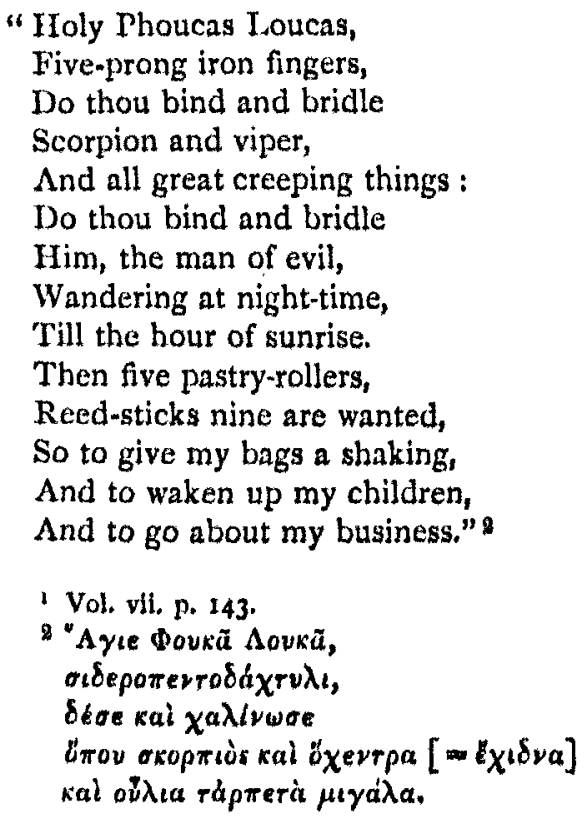


Folklore from the Southern Sporades. $\quad{ }_{1}^{6} 3$

Another charm guards you against ants. ${ }^{2}$ With a blackhandled knife make the sign of the cross thrice, singing each time. The first three lines contain a nonsensical jingle on the word ant, thus :-

"Here's an ant, I have him fast,

'Tis an ant, the first of ants,

And they are first to ant him.

Come and gather up your swarm,

And then away to pasture.

Find a tree that bears no fruit,

Take that fruit and eat it;

Lest I should go and find the black boar's fleece,

- And then cut through your gullet." "

Another kind of charm is the "binding of the tongue" $\langle\gamma \lambda \omega \sigma \sigma o \delta \delta \mu a\rangle$, which protects you against evil spirits. I find in my MS. a charm against the witch called Gelou, and against all supernatural things, called a "tongue-binding." It begins with an invocation of the Trinity, and proceeds:

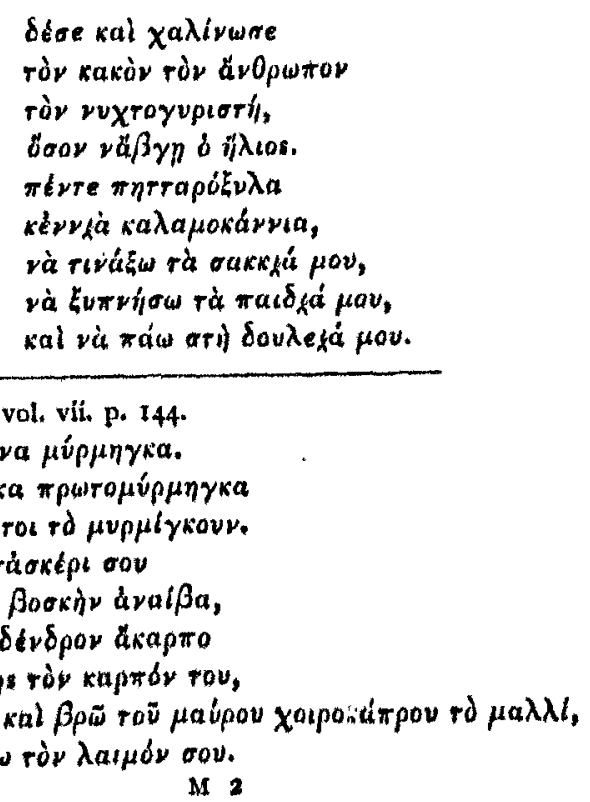

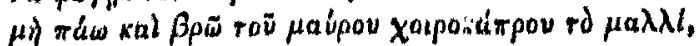

- Compare vol. vii. p. I44.

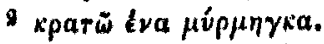

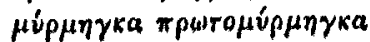

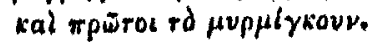

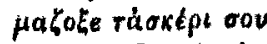
ral 'orn Pookìv a $v a l \beta a$,

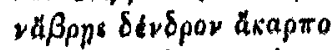
và $\phi \dot{\alpha} \gamma p$ ròv кaprob rov,

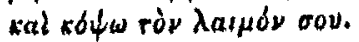




\section{Folklore from the Southern Sporades.}

"As thou didst free the prophet Daniel when he was cast like a sheep to the lions, and didst break his three chains in Babylon, so save me also, the servant of God, N or M. . . . In the beginning was the word, and the word was with God, and the word was God. As thou didst banish the devils from paradise, so keep my enemies far from me, and bind their tongues and their reason, and let them not be able to speak or to eat, or see with their eyes: . . . . Franks, Armenians, Turks, and every evil and passionate man or woman, young and old, believers or hereticks, who hate the holy baptism and the Christians, poisoners and stranglers." In this passage are several old words, such as $\dot{\phi} \phi \theta a \lambda \mu \dot{s}$.

The Evil Eye has already been alluded to; and it is one of the commonest means by which these malign influences are supposed to work. I am happy to be able to present the Folk-Lore Society with another charm potent against it, from the same source as the last. You must put water in a dish, and oil in a cup. Then take a drop of the oil on your finger and let it fall into the water thrice, each time repeating this charm:

"Two eyes have cast a spell on thee And three again have raised thee, Christ and the Holy Trinity." 1

With the water and oil then besprinkle the person betwitched forty-one times. In my MS. Barkavla, or bewitching by the Evil Eye, is often mentioned, and one charm is given to counteract it. This consists of the usual cross and letters, with prayers such as, "Let Christ arise," and allusions to King Solomon. Here the crosses are longer than usual, and more in number, in consequence of the subtle nature of the afliction.

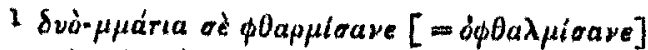

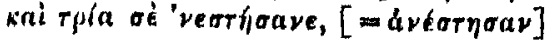

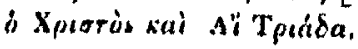


Folklore from the Southern Sporades. 165

For all common diseases and aflictions the wise woman has her charm, or her prescription, generally both. In Cos many of these folk-medicines are left out all night when there is a full moon and the stars are visible; the charm is recited over them; next day the concoction is taken, and

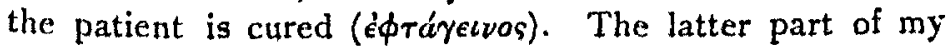
magical MS. is full of charms for childbirth and the like, but unluckily the pages are all torn in half so that little can be made of them. One or two others, however, are complete. Here is one for the ague: " "To cure the daily ague read this three times, and fasten upon the left hand a thread of cotton in three knots, and write it upon a little white root (?); wash it off with water, and make them drink it: Stand the sun in the east, and stand he away from the moon, and stand the ague afar from the servant of God, $N$. or M., Amen." This is followed by the same cross sign as given above (p. 157 ), and by a number of meaningless letters. Other charms for the ague follow. The tertian ague is cured by writing crosses and signs on the patient's cheek, together with those blessed words Phison, Gihon, Tigris, and Euphrates, or that passage which begins: "In the beginning was the Word," with an invocation of St. John the Forerunner; "Christ is born-flee away ague from the servant of God; Christ was crucified-flee away ague from the servant of God; Christ is risen-flee away ague from the servant of God, N. or M., Amen," 2 St. John is supposed to be especially potent against ague, because his

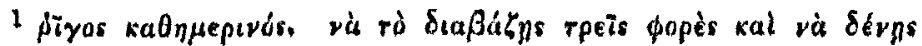

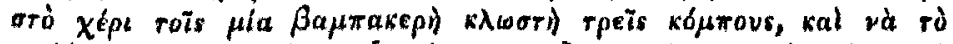

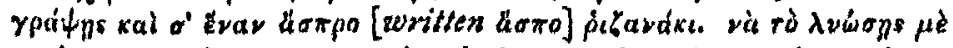

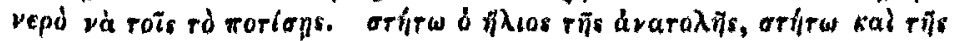

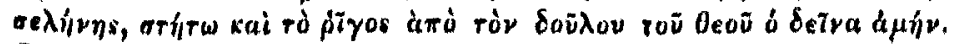
Crosses and letters. [Fol. 3.]

Reginald Scot has many charnıs againat ague, consisting of scriptural words and crosses diversely used, Discovery, p. 270 foll. Ilis charms specify all parts of the body in detail, as do those of my MS, see pp. 248,263 . 


\section{I66 Folklore from the Southern Sporades.}

head shook so when Herod cut it off $;^{l}$ and he is invoked again in the following charm against sunstroke, which comes from Cos: ${ }^{2}$

"Christ our Master made his call, And he calléd all the $\Lambda$ postles. One and all they ate, they drank, Not forgetting God to thank ; But St. John the Forerunner Eateth not and drinketh not, And for God no thanks has got. Christ our Master spoke and said : 'St. John, St. John, what ails thee? Thou eatest not and drinkest not, And for God no thanks hast got!' ' On the road by which we came

See vol. vii. p, 147 ,

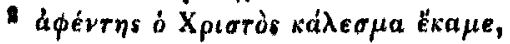

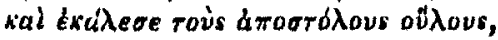

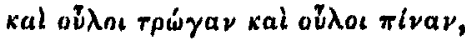

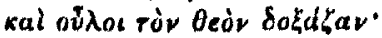

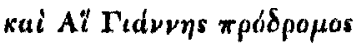
$\mu \eta \delta \delta$ rowrel $\mu \eta \delta$ तivet

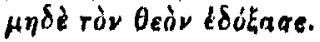

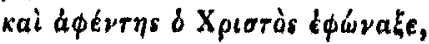

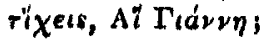

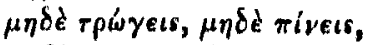

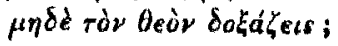

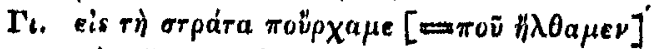

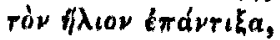

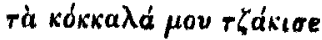

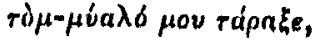
\& $\beta \delta$ о

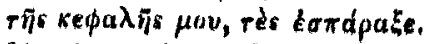

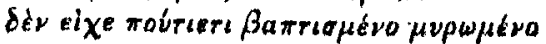
kal ' $\pi \dot{u} r a ̆ y ı a ~ \pi \varepsilon p a \sigma \mu k ́ v o v$.

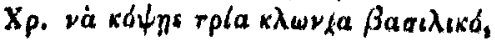

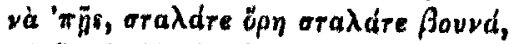

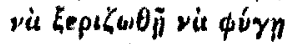

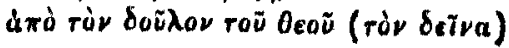


Beat upon me the sun's flame!

Bruised my bones, and shook my brains,

Tore me two and seventy veins

In my head : no antidote,

Nought incensed or dipt in holy water,

Nor overstept with holy things.' 1

'Cut three basil twigs, and say-

To the rocks and hills away!

That it may uprooted be,

And from N. or M. God's servant it may flee." "

The last four lines are to be thrice repeated. The charm is worked thus: Water is placed in a bottle, with three sprigs of basil atop, and is then held upside down over the patient, being moved through the air in the form of the cross over his forehead and the two ears. As the water flows, say the charm thrice. A plate ${ }^{2}$ is held to catch the water, and the sick man drinks thrice of it; the residue is thrown in some place where no one goes, for it is holy.

In my MS. I find the following charm against erysipelas. ${ }^{8}$ "Write the same characters as were written for the tertian

I This is done when the priest bears the holy elements through the church, and sick folk and children are laid down for him to walk over.

- A plate with an Arabic charn written upon it is preserved in the Pitt. Rivers Muscum at Oxford.

${ }^{8}$ y

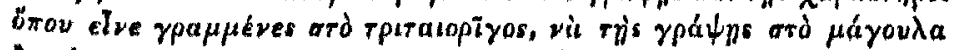

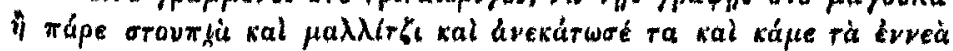

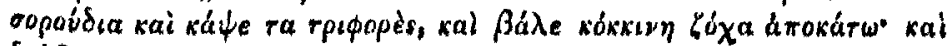

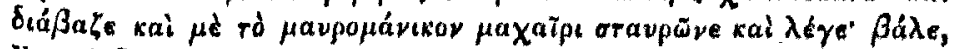

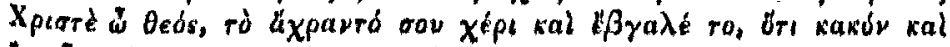

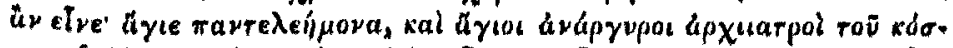

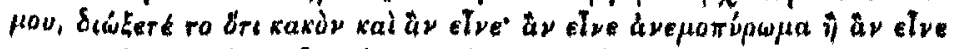

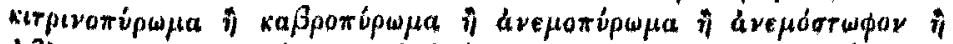

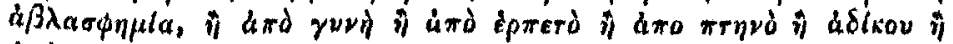

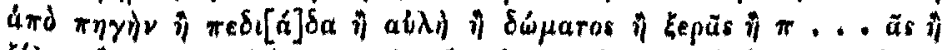

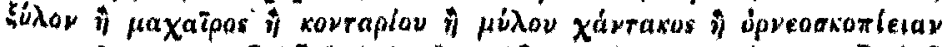

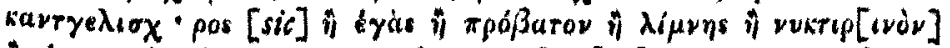

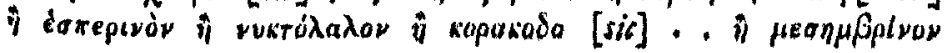




\section{Folklore from the Southern Sporades.}

ague; write them, I say, on the cheek. Or take some tow and wool, and mix them together, and make nine lumps of it. and singe it thrice and place a red cloth underneath. Then repeat the charm, and with a black-handled knife make the sign of the cross, and sing : O Christ our God, with thy undefiled hand cast forth the mischief whatsoever it be ; $O$ Saint Allpitiful, ${ }^{1} O$ ye saints Cosmas and Damian, first physicians of the world, chase away the mischief, whatsoever it be: be it erysipelas, or the jaundice, or [some complaints which I do not understand], whether it come from woman, or creeping thing, or bird, or unrighteous thing, or fount, or plain, or yard, or roof, or water, or dry land, or ... or wood, or knife, or bludgeon, or mill-race (l), or bird-scarer's tower, or Kali-Kazaros (?), or goat, or sheep, or marsh, or a thing of the night or the evening, or night-talker, . . . . or at mid-day, seen or unseen, deaf, dumb, or speaking; as flow the founts, or rivers, or springs, so may this mischief flow and flee, whatsoever it be." Then follows a list of diseases, and the writer adds, "or be it supernatural from the Nereids, as

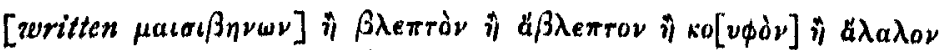

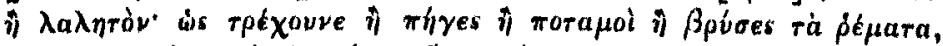

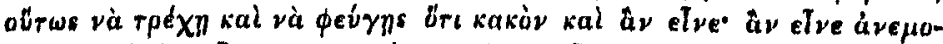

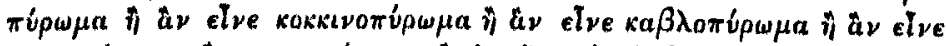

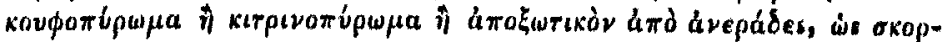

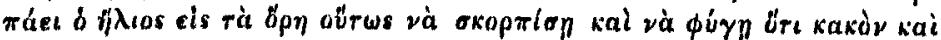

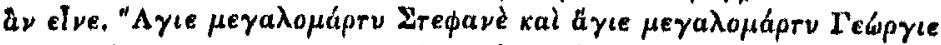

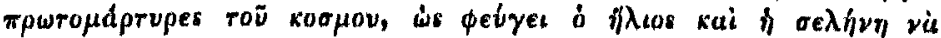

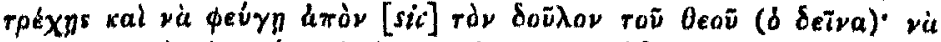

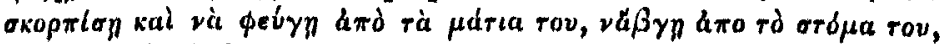

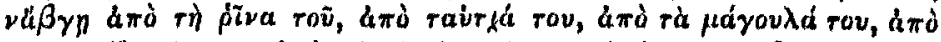

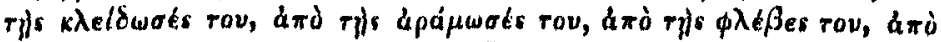

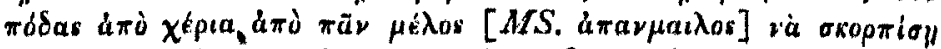

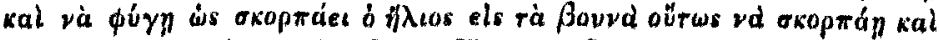

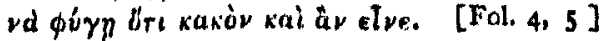

1 This is the name of a Greek saint. 
the sunlight scatters upon the hills, so may the bane scatter away and flee, whatsoever it be." Next comes an appeal to St. Stephen and St. George, with this: "as the sun and the moon depart, so may this depart from the servant of God, N. or M., let it scatter and flee away from his eyes, may it go forth from his mouth, may it go forth from his nose, from his ears, from his cheeks, from his joints, from his knuckles, his veins, feet and hands, from every part of. him may it scatter and go, as the sunlight scatters upon the hills." 1

No vade mecum of folk medicine would be complete without its love-philtres; and mine has two or three. These have been much used; the pages are turned down and well worn with ancient thumbs. For example: ${ }^{2}$ if you would win the love of a girl or woman, take a red apple on the Sabbath Day (Saturday), and write upon it a number of mysterious signs with blood from your left thumb; then give it her to eat, and she will love you. May we not believe that the ancients, when they threw an apple in their lady's lap, had worked some such charm over it first? Or you must get an egg "laid on a Thursday by a black fowl; write upon it certain cabalistic words and signs; recite them and say: "As this egg is burnt and boiled, so may her heart be burned, and her entrails (giving the lady's name),

'See ahove, p. I65, note.

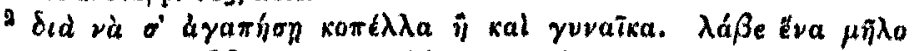

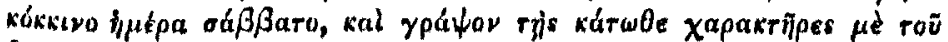

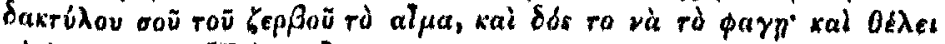

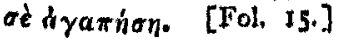

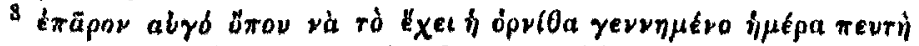

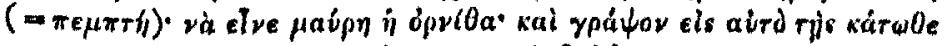

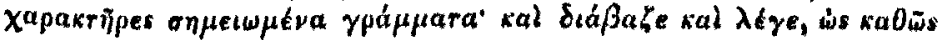

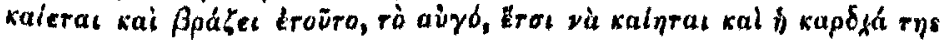

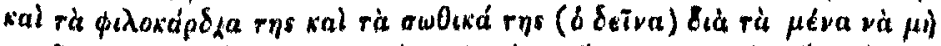

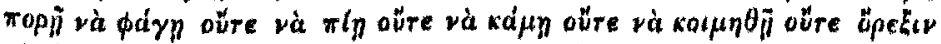

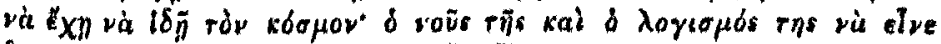

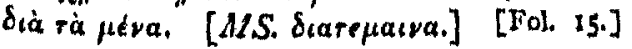




\section{I70 Folklore from the Southern Sporades.}

for my sake; may she have nothing to eat, or to drink, may she be able to do nothing, nor to sleep, may she have no desire to see company, may her mind and her reason be mine." If this seem rather too drastic, you may take vermilion and musk, ${ }^{1}$ yolk of egg, rosewater, and burn a little of your own hair; mix them all together, burn them to ashes. Make ink out of these, and write on your left palm "this ornament" with a crow's feather. The "ornament "is two rude concentric circles, and meaningless words within them. In Cos, a less innocent charm is used by old hags who bear a grudge against some girl. Certain black ants with a big

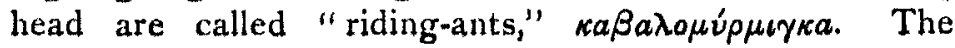
witches cut off these heads and soak them in wine, which they leave out all night. They then put a drop of this concoction into wine, and give the wine to the girl's lover to drink. It is believed that he will at once attempt her honour.

There remain a few miscellaneous charms which it may be interesting to mention. When you are in chains and in prison, for example, all you have to do is to read the first Psalm" a hundred and one times, and "you will be surprised to find yourself free." When you want your enemy to flee from the place in which you are, read the thirtieth Psalm when there is no moon, on three successive days, morning,

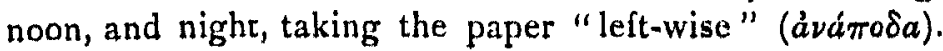
But one there is which will prove a godsend to the harassed parent or schoolmaster:" "How a child may

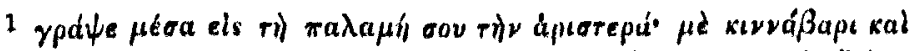

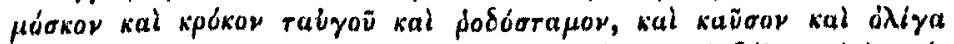

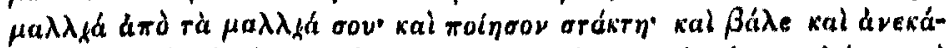

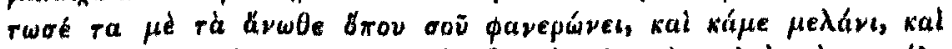

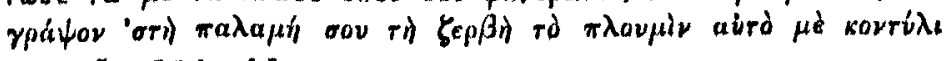
коракой. [Fol. 16.]

* In our version this is the second.

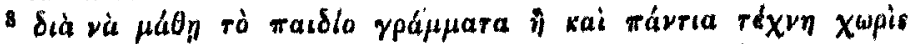

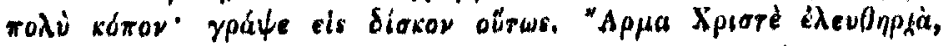

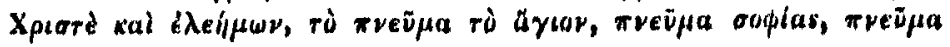


learn his letters or any art without much trouble. Write this on a plate: Christ, freedom, Christ is pitiful; the Holy Spirit, Spirit of Wisdom, Spirit of Rhetoric and Reading, Spirit of Jesus Christ the Son of God. Grant the enlightenment of the servant of God, N. or M., holy things for the holy, the holy Spirit, and may the power of the Highest overshadow him: Amen. When you have writ all this, let divine service be performed over the plate for seven days. Then wash the plate ${ }^{2}$ with holy water of the Epiphany, and make the boy drink of it for three days. You will be astonished to see how he will learn his letters."

Here is a charm for rendering oneself invisible." "On May $x$, kill a snake, take his head and plant it in a certain place, and put in his mouth one bean. Plant it, and when the beans grow, gather them all, don't lose a single bean. Take a mirror to behold your countenance in, and put the beans in your mouth one by one. As soon as you find a bean, which being in your mouth you cannot behold your countenance, take good care of that bean; and when you wish that no man may see you, put it into your mouth." The man who wrote that had a sort of humour in him.

There is in the MS. one curious monster spoken of, the "half-head." "Beyond Jordan," we are told, "stands a

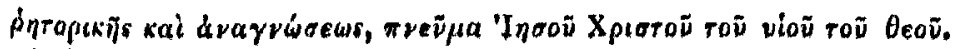

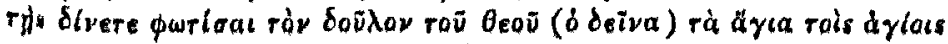

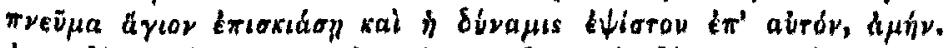

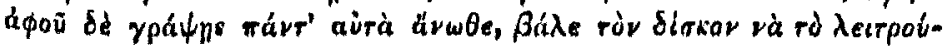

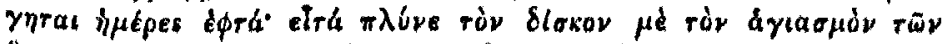

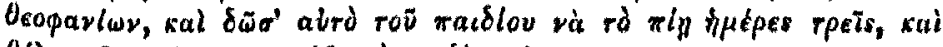

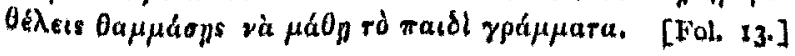

'See alove, p. 159 , note.

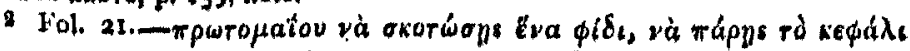

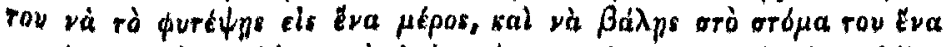

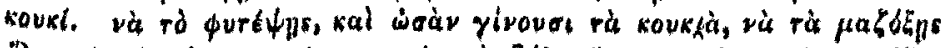

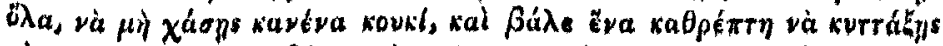

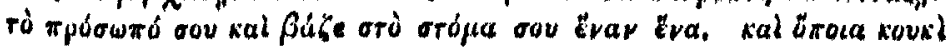




\section{$\mathrm{I} 72$}

\section{Folklore from the Southern Sporades.}

youth, the hateful Half-head; and cries with a loud voice that he wants man's flesh to eat. Then came a voice from heaven, which said '__ something or other in reference to King Pharaoh and the kiss of Judas, our Lord, the Virgin Mary, and Aaron, adding: "Depart and flee from the servant of God, N. or M." Another charm ${ }^{2}$ is given to get rid of this creature, to be repeated three times. "In the beginning was the word," is the first sentence; St. John and the Virgin are invoked, but there is nothing of interest to us in it. The "half-head" is probably the monster, familiar in the east, who is merely a shell; complete before, but hollow behind. ${ }^{8}$

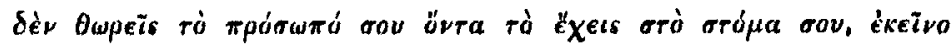

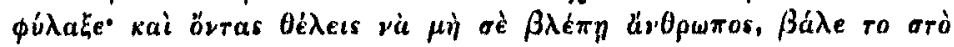
orija oav.

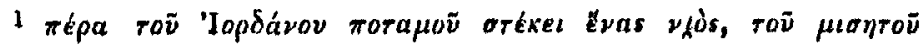

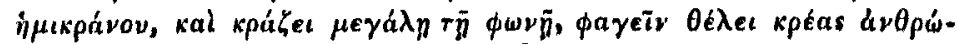

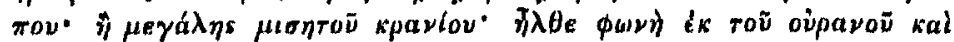

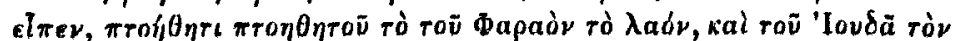

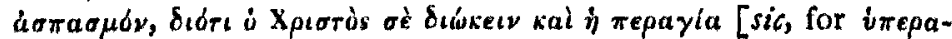

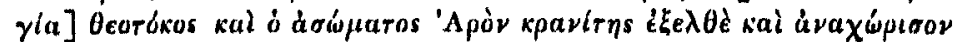
a $\pi \dot{o}$ roũ $\delta o u ̈ \lambda o v$, etc.-Signs and letters (fol. II). This has apparently been copied from an older document, or written down from memory, and much blundered.

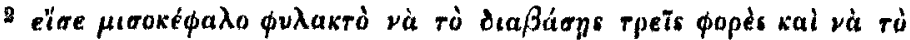

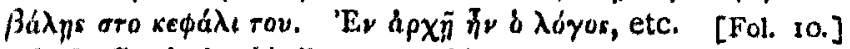

* Mr. Crooke has kindly sent me this note :

In the "Story of Janshah." (Burton, Arabian Nights. Library Edition, vol. iv. p. 279.)

" Presently they came upon a spring of running water in the midst of the island, and saw from afar a man sitting hard by it. So they went up to him and saluled him, and he returned their salan, speaking in a voice like the whistle of hirds. While Janshah stood marvelling at the man's speech, he tooked right and left and suddenly split himself in twain, and each half went a different way."

Burton notes that the Badawi hold whistling to be the speech of devils [cf. miners' objection to whistling underground]. Burckhardt got a bad name by he ugly habit.

"The Arabs call Shikk (split man) and the Persians Nimchahrah (half-face) 


\section{Folklore from the Southern Sporades.}

\section{II.-Vroukblakas and Kalikagari.}

The Vroukolakas, or Vampire, is familiar to all students of modern Greek life. Persons guilty of abominable crimes, those who die under a parent's curse, or who die excommunicate, all children conceived on one of the great festivals of the Church (when abstinence is ordained) become Vampires. They arise from the tomb any night except Saturday, and live by sucking the blood of living men, especially of their own nearest and dearest. You may know the Vampire if when his grave is opened-which should be done of course on the Saturday night only, as the creature then cannot get out-the body is found whole and undecayed, the hair and nails perfect. To lay the Vampire requires different methods according to the cause of his being such. ${ }^{1}$

a kind of demon like a man divided longitudinally: this gruesome creature runs with amazing speed and is very cruel and dangerous."

The same account of the Shikk is given by IUghes, "Dictionary of Islam," 137. The Nasnats is a similar beast, the offspring of a Shikk and a human being.

The Iladal, a Bombay demon, is plump in front, a skeleton behind. So the Ellekone of Denmark is captivating to look at in front, hollow behind like a kneading trough. (Grimm, Tewt. Myth., vol. ii. p. 449.)

The Daitya of North India is beautiful in front, behind only a mere husk without a backbone. (Croake, Popular Rel., vol, ii. p. 255.)

'The following passages describe the common practice. MS. III. of the Canons (1560), fol. 59 :-

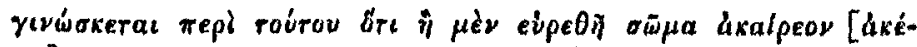

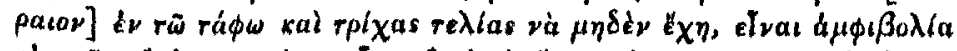

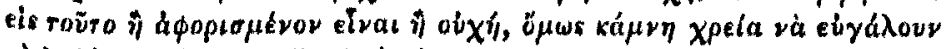

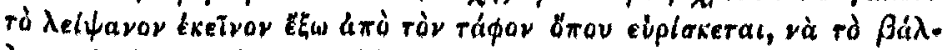

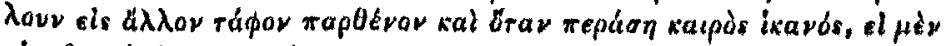
èje日

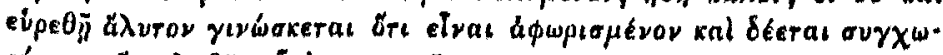

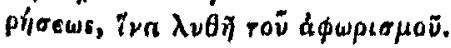

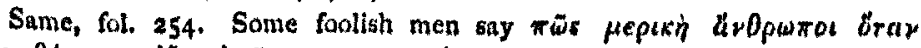

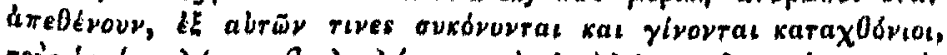

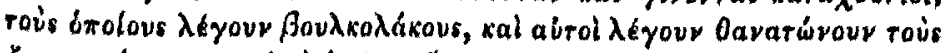

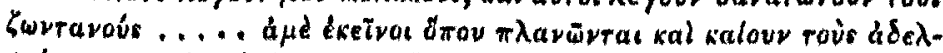

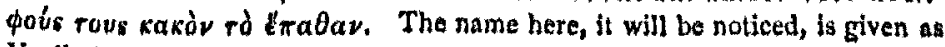
Voulkolnkos, 


\section{Folklore from the Sonthern Sporades.}

If he were excommunicate, a service of pardon revoking the sentence of excommunication sets him free. If not, he must be moved to another "virgin" tomb, or even burnt to ashes. Old travellers were sometimes witnesses of this horrid ceremony; but although the belief is still strong, the burning is probably no longer practised.

As it is not my plan to collect the evidence already to hand, I say no more of the Vampires, but beg leave to refer students to Bernhard Schmidt's account of them in his Volksleben der Neugriechen, pp. 157-I7I. Schmidt has also a chapter on the Kalikazari, and some of the verses I have collected occur there.'

These curious monsters are believed in all over the Greek world, and they go by a variety of different names:

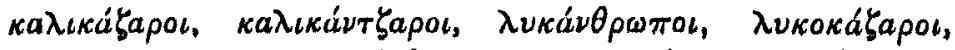

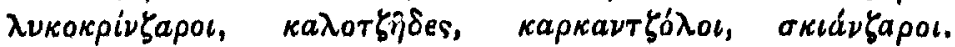

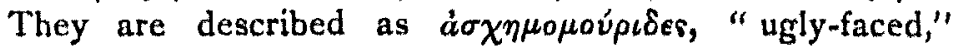

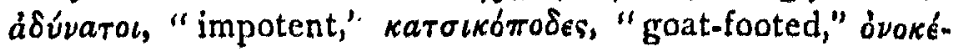
$\phi a \lambda o u$, "ass-headed." Besides these associations with animals such as wolf, ass, and goat, they are connected in different places with other animals as to head, hands, or feet, and are believed to be fond of dance and of women. There is clearly an accretion here of werewolf legends, with perhaps a reminiscence of the satyrs.

Children conceived on the day of the Immaculate concention-(March 25), and so born on Christmas Day, are supposed to be accursed because they impiously mimic the beginnings of our Lord's life on earth, and when born they become Kalikazari. They are not born as infants, but by the power of Beelzebub they become full-grown men and women, or take upon them some other shape. They remain on earth for twelve days, until the Epiphany; for on that day, by the baptism, the whole earth was made holy, and all demons are forced to depart from it. The Kalikazari flee away, crying out-

\footnotetext{
1 Pages 142-152.-My authority is Mr. Zarraftes.
} 
"Flee away, that we may flee:

Priest with pot-belly, here is he,

With his holy water brush,

With the sprinkler too for us ;

He will sprinkle us about,

And defile us without doubt." 1

Until these twelve days are past, the monsters leave in their cradles the semblance of babes, and assuming the form of Kalikazari, wander about, living in deserts and dark caves, feeding on snakes and lizards. Sometimes, it is said, they eat women, whom they love very much. By the light of the moon they dance at night, in company with any handsome women they can get hold of, or any inquisitive person. Women that lose their way, if not pretty enough to dance with, serve them for supper. They dance till the black cock crows, and then they must stop. Some enter the houses by the chimney, and there sit at table and eat and make merry, especially in the kitchen; and they take delight to insult ${ }^{2}$ the sleepers of the house. When they hear a black cock crow, they evanish like smoke through the keyhole. To prevent their mischief, these keyholes or boltholes" are stopped up with a skein of flax. Before the exit is free the Kaljkazari have to count all the threads in the skein; and as they always take care to look at the

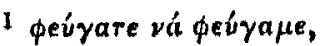

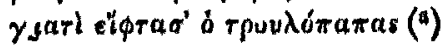

$\mu \varepsilon r \eta \nu$ d $\gamma$ เuaroũpa rov,

cal $\mu$ siv Bpexroüpa rov,

ral ò̀ $\mu a \tilde{s}$ tpparrion

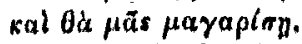

The holy water would be thought defiling by these monsters.

aipoĩar, mingunt.

s $\mu \pi a \rho o ́ t \rho \nu \pi a, \kappa \lambda e t \delta \delta r p \nu \pi a$.

(4) Schmidt, who gives a variant of these lines $(p, 151)$, explains this word as a gibe, "pot-belly priest." My informant took it as referring to the priest's, tall hat (roüp $\lambda a$ or rpoũ $\lambda \lambda a$ "dome, $a p e x "$ "). 


\section{I76 Folklore from the Southern Sporades.}

keyhole the first thing on entering, to see that their retreat is open, they spend all the time till cock-crow in counting, and can do no harm. They appear suddenly to millers, and make fun of them; and if a woman comes to the mill to grind, they do the grinding for her, and can hardly be prevented from making a meal of herself. While the miller sleeps, they take some flour and work it into honey-combs, ${ }^{1}$ which they eat; then they defile the rest of the flour, the other food, and the ashes." The Kalikazari flee away when you

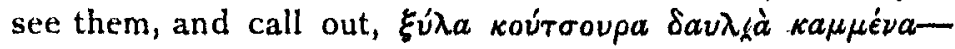
"Wood, logs, brands all burnt."

The people believe that the Jews worship some creature with the head of an ass, ${ }^{3}$ and accordingly speak of them as

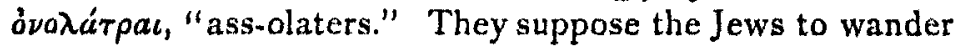
about from Christmas to Epiphany, looking for Moses, whom they desire to throttle, it is hard to see why, and thus the Jews are confused with Kalikazari. For this cause they call the Kalikazari $\sigma a \beta \beta a \tau \iota a \nu o l$, " sabbatarians."

When at the Epiphany these monsters depart, they go under the earth, and there remain for the rest of the year, sawing at the trunk of a gigantic tree which upholds the earth. Their aim is to destroy the whole world; but they never quite get the job donc. Christmas comes round once more, and away they fly; and during the twelve days that follow, the tree grows whole again.

In Cyprus, the Kalikazari are very fond of cakes called $\lambda o u \kappa o u \mu a \hat{\delta} \delta s$. The people leave them honey to eat in order to make them kind; they also leave a plate full of these cakes by the hearth. The Kalikazari entering, cry out:

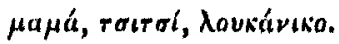

$$
\begin{aligned}
& \text { "Bread, cheese, sausage!" }
\end{aligned}
$$

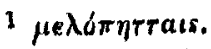

- They also olpoṽour els rò orópa rïy raidiwr when they sleep with mouth open: mingunt in ora puerorum.

- The reader will remember the famous grafito of the Domus Geloniana at Rome. 
But the time is a fast, and nothing of the kind is to be had; so the man who waits answers :

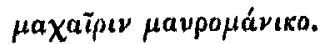 \\ "Black-handled knife!"}

This charm startles the monsters, who thus say hurriedly, as though ready to be content with anything:

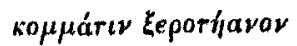

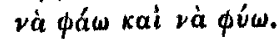

"A bit of dry cake, that I may eat and go."

He eats then what is provided and departs.

I have now a number of notes on various customs and superstitions, and I will begin with customs observed on some special day.

\section{III.-Cos: Times and Seasons.}

On New Year's Eve the brute beasts are supposed to be endowed with reason and speech, to bear witness for good or evil according to the condition they may be in. Hence, on the day preceding the last night of the year, they are specially well fed and taken care of.

On January 6 takes place the ceremony of Diving for the Cross, which is described in a pretty little sketch by a Greek writer, Argyris Eftaliotis. ${ }^{1}$ By the Scala, or quay, of the town of Cos, the cross is thrown into the sea, and it is a point of honour with all the young pallikars to fetch it up. A collection is made in the villages of the island for the successful diver. There is some danger for him if the sea be rough or the weather cold. The First of ApriI is called rd

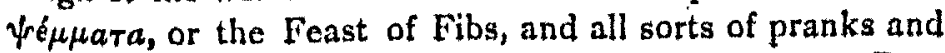
jests are made. On the vigil of the 'Aváaraís, Easter Day,

1 Transhated in Tales from the Jsles of Groece, being skutches of Modern Gresh Reasant Life, by Argyris Eftaliotis, Dent, 8897 .

vol. $x$. 


\section{I78 Folklore from the Soutliern Sporades.}

a lamb or a kid is killed, put in a dish, and roasted in the oven, and afterwards eaten. A cross is then made over the door of the house. On Easter Day, a straw image is made of Judas which is hung up, shot at with guns, and finally burnt.? On the First of May, as elsewhere in Greek lands and here, garlands are hung over the doors, made of flowers, with oxópia (heads of garlic) in them. These are left hanging till they drop, as a protection against the Evil Eye. A curious custom is usual on June 24, the Birth of John the Baptist (ó moó $\delta$ poros, "the Forerunner"). John is here called

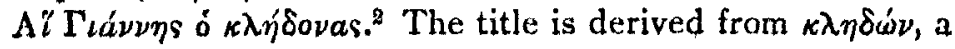
"call," or "voice of omen." I have no particulars from Cos of the divination described in the authorities quoted above, though I have reason to know it is practised. But in Cos there is an addition to the ordinary custom. Villagers flock into the capital for this day, and some representative of each village bears a ring or some recognisable token. These are dropped into a cup of water, which is left out in the open air all night. Then in the morning all gather together; a woman is chosen who knows many songs, and she repeats a nice and a nasty song $(\ddot{a} \sigma \chi \eta \mu o)$ alternately.

The same custom is observed clsewhere. A photograph of Judas from Thebes is shown herewith. Mr. M. E. Marringe writes: "Perhap a peronification of winter now to be killed. In IIeidelberg, winter as atraw man, still driven out of the town on Laetare Sundny, three weeks before Enster, see Grimm, Myth. (Gött, 1854) p. $724 \mathrm{ff}$. Uhland, Abhanallungen abor das Volksliad, chap. i. In all or nearly all the sham fights between Summer and Winter so widespread in Germany, Surnmez wears ivy and winter straw."

- My informant derived this word from $\kappa \lambda \nu \delta \omega \psi$ (quasi $\kappa \lambda i \delta \delta o v a s)$, because "storms recur al that season." This, however, is a nistake. See A. Thumb, Zü Nougriechischen Volkskundle, Der K'lidonas (Zeitschr, der Vereinu f. Volks.

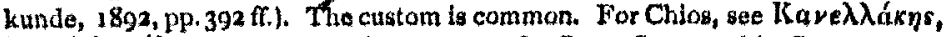
Xıa cà 'A vádekra (Athens, 1890), p. 321 ; for Crete, Jeannarakis, Cretas Volksieder (Leipz., 1876), p. 340, both these on the Feast of St. John. In Cyprus

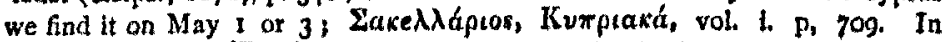
Thessaly, May I: 'Earia (r8go) vol, i. p. 26x. In Aegina, the Feast of John

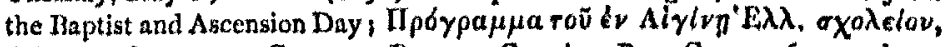
Athens, 1890 , p. t. Compare Passow, Carmina Pop. Cr., p. 614, and sce above, page 155 . 
After each song, a boy draws out one of the tokens at random; and the song is taken to apply to the village that owns it. This, as may be imagined, is the cause of much fun and jollity, On the vigil ( $\pi a \rho a \mu o \nu \eta$ ) of St. John's Day,

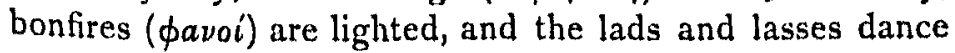
around them. The lads bind a black stone on their heads, signifying that they wish to become as strong as the stone; they make the sign of the cross over feet and legs, and jump over the fire. As to these bonfires, an old woman of Cos suggested the following explanation, which is a good example of myth-making to explain ritual. "Doubtless," said she, "Elizabeth had arranged with her friends to announce in this way the birth of her expected son; and the custom was kept up to commemorate it." The first three days of August are called the $\delta \rho l \mu a \iota s$. On these days women do no work (for it would not prosper), and wash no clothes (for they would soon wear out). The eleven days following are supposed to foreshadow the weather of the succeeding months: as the fourth is, so will September be, the fifth shows October, and so on. The fifteenth is the feast of the Assumption, closing a fortnight's strict fast. On Septem. ber $1, a$ kind of tithe-offering is hung up in the houses, consisting of a bunch of red grapes, a pomegranate, a quince, and a bit of cotton.

At the Geodávela, or Feast of the Epiphany, twigs of olive are dipped in holy water and hung up by the icons

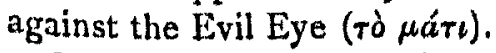

One quaint custom remains to be mentioned. In the centre of the island, at Antimachia, Kartarmita, and thereabout, come the month of March every one picks a switch and flicks the cattle with it, crying: Mápr and up with your tail!" The cattle, if well and strong, at once flourish their tails and gallop away. The ceremony is supposed to be actually healthy for them, and to bring good luck. It is never done at other times, only in March. So far it is nothing out of the way, though one is reminded of 


\section{Folklore from the Southern Sporades.}

the beating of animals to secure fertility, ${ }^{1}$ or of women at the Lupercalia at Rome; but the odd part is to come. On the eve of March I, a girl sends to her lover, ${ }^{2}$ or the lad to the girl, three strands of thread in three different colours twisted together, and hidden in a basket of fruit or sweets or what not. This is bound about the right wrist, little finger, and big toe. Next morning, the lover who has received this seeks the lady and tries to get speech of her apart; if he succeeds, he flicks or pulls the skirt of her

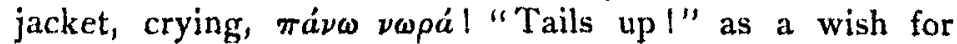
health and strength. The threads are thus worn till Easter Day, when they are cast into the fire and burnt, as something holy. It would be unlucky for any one else to get hold of them.

Calymnos. From this island I have only a few notes. Five times a year-at Christmas, Easter, the Holy Apostles (June 29), on September 1 , and St. Andrew's Day (late in November) - the people make cakes, sweetmeats, \&c., and

$1 \mathrm{Mr}$. M. E. Marriage kindly sends me the following note :

"Elard IIugo Meyer (Deutsche Volkskunde, Strassburg, 1898, p. 138 ff) in speaking of cleansing customs which still obtain among herdsman at the first driving out of the cattle to pasture (p. 14I) tells how in the Ciresenthal Baden the beasts are beaten crosswise on the back with palm. In Westphalia on the first of May young cnws that have not yet calved are switched thrice on back, flank, and udder, while a rhyme is said over them to bring milk. So also by the lower Rhine and in Mecklenlurg. Mountain ash and hazel switches cut under special conditions are used. Meyer mentions several other cases, among them an anciunt Indian custom.

Connected with the beating of the animals would seem to be (p. 142) the cracking of whips over them to drize away the witches (ITexen auspatschen) at Whitsuntide.

Truly none of these customs take place in Mfarch, but that might perhaps be accounted for by the difference in climate.

The Pelzenichel customs in Ileidelberg (if indeed they have any connection with these, as for instance, by way of beating out the evil spirit of sickness) hold on two successive days, Klein-und Gross-Pelzenichel, about a week before Christmas-I forget the date. Children disguised and in sackcloth run about the street switching passers-by."

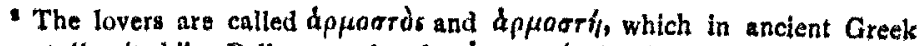

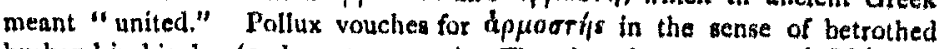
" "Marband in his day (and century A.D.). The threads are called o Mápris, 
lay them upon the tombs of their dead. Children, beggars or strangers may eat them. The feast at the tomb was a regular institution amongst the ancients, and this is no doubt a survival of it. On May 21, in February before the Carnival, and at one other time, they make dishes of macaroni and cheese, or boil corn, and the dishes are taken from one house to the next. The same quantity is brought in as was taken out.

Miscellaneous Superstitions and Omens. The Evil Eye

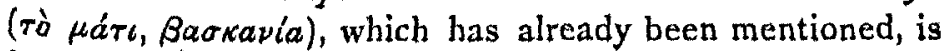
feared in these islands, as everywhere. Skulls are set up in the vineyards on stakes, to ward it off, in Rhodes, Cos, and Samos. On the lintel of a new house a piece of wild onion

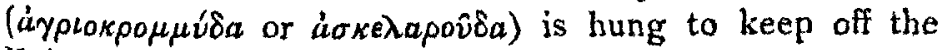
Evil Eye. There is a Sacred Tree in Cos, near the village of Aspendiou, beside a little chapel. Opposite the tree there is a small window in the chapel. $A$ sick child is brought in by the door and passed out through the window, if not too big, three times; then some prayer is said, and a rag of the child's clothes is hung on the tree. Large trees are for the most part haunted (orou $\chi \epsilon \iota a ̂ r a)$, and if you sleep under one of them the spirit strikes you $(\chi T u \pi \dot{a} e l){ }^{l}$ Rivers and springs are haunted likewise; the spirits usually appear as beautiful women, but sometimes they take the sliape of foam. Spirits of the springs throttle men. You must never sweep after sunset, for this is a sin. A sneeze means that some one is speaking of you; a loud sneeze that he is speaking ill of you. People on hearing a sneeze utter some prayer or ejaculation, in which the title of терibpopos ("run-about") is given to the Deity. A noise in the car betokens some evil which is to befall you. If a hen makes a noise like crowing, it is a bad omen." When a woman

'Cos, Samos.

"Mr. Marringe sends me the couplet :

A whistling maid and a crowing hen

Are hateful alike to God and men.

Compare aluo Terence, Mhormio, iv. 4, 27, grallina caciuit, a portent. 


\section{I82 Folklore from the Southern Sporades.}

hears it, she generally throws the hen down the chimney upon the hearth; if she be a virtuous woman, the hen is killed. The following plan tells the sex of a child which is to be born. A bone taken from the head of the fish called

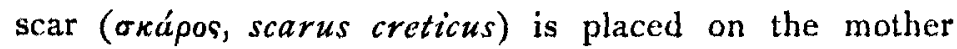
without her knowing: the child will be of the same sex as the next person she calls. One of these divining bones is here exhibited.' Treasure trove will turn into charcoal

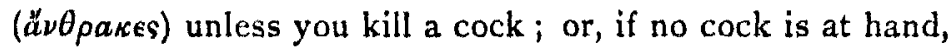
you may cut your little finger and drop the blood on the treasure. An old woman once showed my informant a piece of charcoal which had been part of a treasure thus transformed. The legend of Fairy Gold is attested for

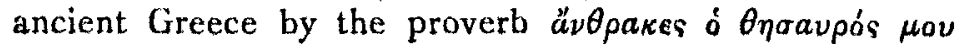
(see Folk-Lore, vol. viii, p. 379). A quaint legend is told of the Lisard. The Holy Virgin, it is said, sighed so bitterly at the death of her son that her burning sighs set her robe afire. No one was at hand to quench it, but the Lizard poured water upon it from his mouth and saved the Virgin. Hence the Lizard is holy, and must not be killed.

It may be interesting to add, that a large kind of hawk is called in $\operatorname{Cos} \dot{a} \chi \epsilon \lambda \omega \nu \circ \phi \hat{a}$, , or the Tortoise-eater, because it catches a tortoise, carries it to a height, then drops it upon a rock and splits it, after which it eats the tortoise. It will be remembered that $A$ schylus is supposed to have been killed in Sicily by such a bird, which mistook his bald pate for a stone.

If one is cutting a fruit, or grinding coffee, or anything that smells, he who smells it must taste. Otherwise a man loses his sight, a woman with child miscarries. If you enter a room where this is going on, the cutter or grinder will always offer you a bit.

\section{IV.-The Bridge of Antimachia.}

Antimachia was one of the cities of ancient Cos, and it atill bears its old name, through the present site is not

' Presented by Mrs. Paton to the Socicty's Museun. 
exactly that of the old city. Not far from the place is an ancient bridge, known locally as $\dot{\eta}$ Kapápa; and of this bridge the following poem tells. :

\section{The Lay of the Kamara of Antimachia.}

Deep down within the river-bed they founded the Kamára :

Each morning they built up the stones, each evening they were fallen.

Then they cast lots, and lo the lot falls to the Master-workman. (Quoth the Master:)

"If I should lay my father there, I get no second father;

If I should lay my brother there, I get no second brother;

If I should lay my mother there, where shall I find another?

If I should lay my sister there, I find no other sister ;

If I should sacrifice my wife, a wife again I'll find me."

Then by the nightingale he sends a message to the lady.

"Go thou and tell my lady fair:

Let her not comb on Saturday, nor Sunday change her raiment,

To the Kamara let her come on Monday in the morning."

$A$ way he flew, the thrice accurst, that thrice accursèd creature,

He flew and told his message:

"Comb not thyself on Saturday, nor Sunday change thy raiment,

To the Kamara see thou come on Monday, in the morning."

She combs her hair on Saturday, on Sunday changes raiment,

On Monday, early in the morn, she comes to the Kamara:

The Master-workman she beholds, and he was full of sorrow.

"What ails thee, Master-workman, say, that thou art full of sorrow?"

"My seal is fallen and is lost deep down in the Kamara."

"O, Master-workman, have no fear, for I will go and find it."

"Come, let her down, the lady fair, deep into the Kamara."

She dug and still she deeper dug; a human hand she findeth.

"O Mister-worknan, take me up; a human hand I've found me."

"Bring rubble-stones and mortar bring, to cover up the lady."

"O Master-workman, haul me up, for I have lonves a-baking!"

"Tis thou hast leavened the loaves, another hand shall bake them: Bring rubble-stones and mortar bring, to cover up the lady."

"O Master-workman, haul me up, for I must rear my children!"

" "Tis thou hast brought them to the birth, another wife shall rear them. 


\section{I84 Folklore from the Southern Sporades.}

Bring rubble-stones and mortar bring, to cover up the lady." "O Master-workman, stay awhile, a dirge that I may sing me, We were three sisters, and all three a cruel doom awaited.

One at the founding of the bath, one at the bridge was buried, And I the last, unhappy I, beneath the deep Kamara."

"Bring rubble-stones and mortar bring, to cover up the lady."

"As I now tremble every limb, so may the whole world tremble:

As now the hairs upon my head, so tremble the Kamara:

And as my tears are falling fast, so may the stone-work tumble." I

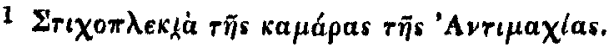

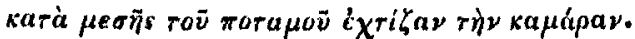

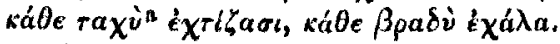

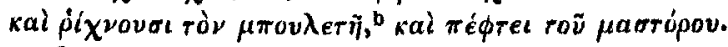

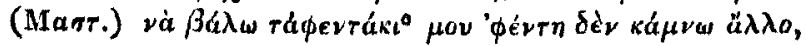

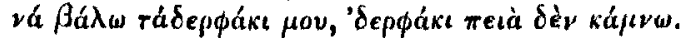

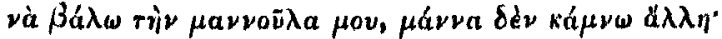

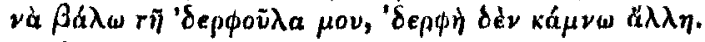

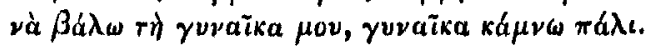

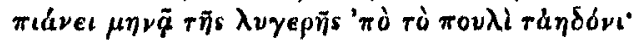

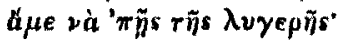

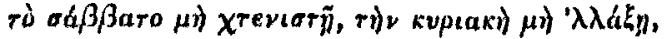

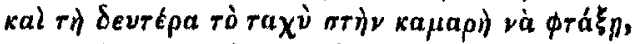

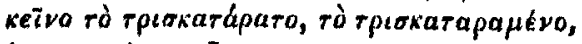

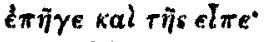

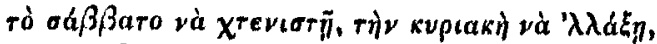

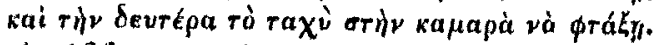

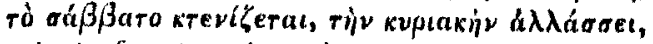

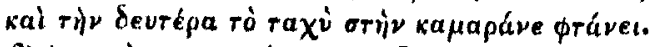

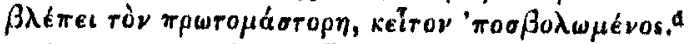

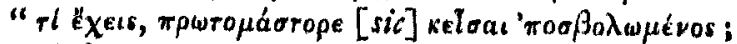

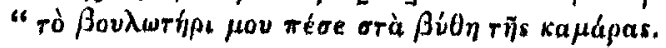

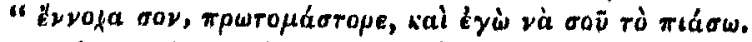

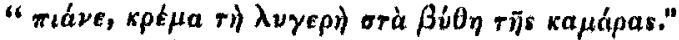

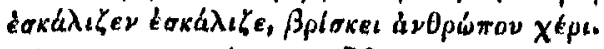

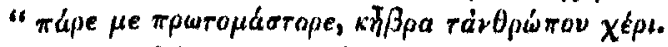

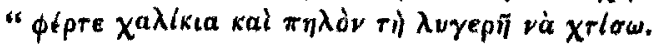

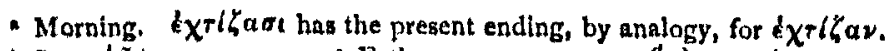

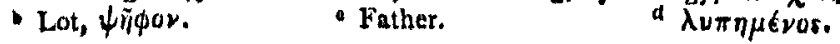


Folklore from the Southern Sporades. $\quad 185$

Such is the song which 1 heard a few months ago in a little coffee-house of Antimachia. There are several Greek poems which embody a similar tradition, the best-known being the Bridge of Arta (Passow, No. 5 I I, 512); but none is so fine as this. ${ }^{1}$ Although in translation much of the dignity of the original has vanished along with its graceful rhythm, I think it is sufficiently clear that the piece has lost little by centuries of transmission from mouth to mouth. There is a strong dramatic force in it, and a severe selfrestraint, which mark the composer as a true artist. In a few words the poet has shown us the struggle between affection and faith, for we must suppose that the masterworkman regarded the sacrifice as a religious duty, as well as a thing due to his employers. Not less remarkable is the Master's interruption of his wife's lament; he seems, as it were, driven to drown her bitter words and get his duty done, or else he must yield. As a character-study it may be compared with the story of Iphigeneia.

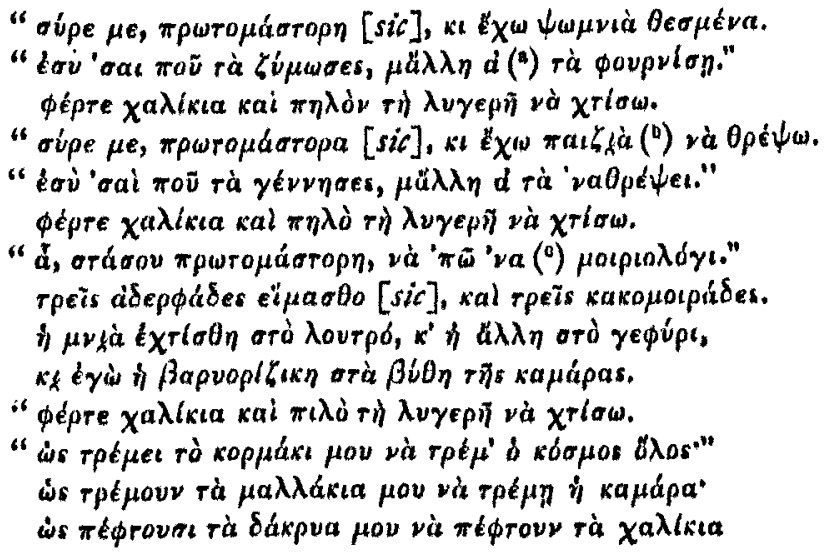

' Other parallels, kindly sent me by various correspondents, are: Gerard, The Land beyond tha Forest (Transylvania), vol. i. p. 278 ; and as a Gypsy tale, hopelessly corrupt and nonsensical, F. II. Groome, Gypsy Folk Tales, 1890.

(4) $\theta$ a.

(b) raisla.

(c) 8 u. 